\title{
TAXONOMIC POSITION OF GUIRATINGIA MENDESI (MEGADESMIDAE) AND THE EVOLUTION OF PERMIAN ENDEMIC BIVALVE FAUNA OF THE PARANÁ BASIN, BRAZIL
}

\author{
M a RCELlo Guimarães Sim ÕeS \\ Instituto de Biociências, U niversidade Estadual Paulista, Distrito de Rubião J unior, Cx.P. 510, \\ 18618-000, B otucatu, SP, B rasil. btsimoes@ ibb.unesp.br \\ LUIZ EduARdo AneLLI \\ Instituto de Geociências, U niversidade de São Paulo, Cidade Universitária, 05508-080, São Paulo, SP, B rasil . anell @@ usp.br
}

\begin{abstract}
The unusual bivalve Guiratingia mendesi is redescribed from the original material. Detailed analysis of hinge and muscle scars allows more refined designation of its taxonomic position and affinities to other Permian bivalves from the Paraná B asin. Guiratingia mendesi is characterized by very small, anteriorly expanded shells, with a great number of muscle striae within the area delimited by the pallial line. A flattened area is noted al ongside the commissure of shell. The presence of a triangular blunt tooth in the right valve allows its designation to M egadesmidae. The absence of accessory muscle scars " $a$ " and " $b$ " and pedal elevator indicate that the genus belongs to the Plesiocyprinellinae, a group of bivalves considered endemic to the Passa Dois Group. Guiratingia mendesi is found, however, in limestones of the Palermo Formation (M iddle A rtinskian), nearly $100 \mathrm{~m}$ below the base of the Irati Formation (L ate A rtinskian). Until now, it was believed that within the Permian succession of Paraná Basin, pre-Irati bivalves were all gondwanic or cosmopolitan. Guiratingia mendesi was an endemic, active burrower that resembles Runnegariella fragilis from the Permian Teresina Formation. This indicates that during Palermo times restricted paleogeographic conditions have existed within the huge Paraná epeiric sea, favoring endemicity, probably in marine bayments close to its margins. The presence of an anteriorly expanded shell in G. mendesi is a condition also seen in other M esozoic and Cenozoic anomalodesmatans, demonstrating the recurrence of shell forms in distinct lineages of this interesting group of bivalves.
\end{abstract}

Key words: Bivalvia, M egadesmidae, Plesiocyprinellinae, Permian, Paraná B asin, Palermo Formation.

RESUM O - Guiratingia mendesi é aqui redescrita a partir do material original, sendo que a detalhada análise morfológica permitiu determinação mais acurada de suas relações de parentesco com outros bivalves permianos da bacia do Paraná. G uiratingia mendesi tem concha pequena, com expansão anterior e grande número de estrias musculares. É notável ainda 0 achatamento ao longo da comissura da concha. A presença de dente robusto, triangular, na valva di reita indica afinidades com os M egadesmidae. Já a ausência de musculatura acessória "a" e "b" e do elevador pedial indica que G. mendesi pertence aos Plesiocyprinellinae, os quais são endêmicos do Grupo Passa Dois. No entanto, G. mendesi é encontrada em carbonatos da Formação Palermo (A rtinskiano M édio, G rupo G uatá), há, aproximadamente, 100 m da base da Formação I ratí (A rtinskiano Superior). Este fato é notável porque, até o momento, acreditava-se que, dentro da sucessão permiana da bacia do Paraná, as espécies de bivalves pré-I rati eram gonduânicas ou cosmopolitas. Guiratingia mendesi foi uma espécie escavadora rasa, endêmica, semelhante à Runnegariella fragilis (Formação Teresina), indicando que, durante os tempos Palermo, condições paleogeográficas restritas já estavam presentes na bacia do Paraná, provavelmente nas áreas marginais, estimulando 0 endemismo. A concha anteriormente expandida de G. mendesi está presente também em outros anomalodesmatas mesozóicos e cenozóicos, evidenciando a recorrência de formas em linhagens distintas, durante a evolução desse extraordinário grupo de bivalves.

Palavras-chave: Bivalvia, M egadesmidae, Plesiocyprinellinae, Permiano, bacia do Paraná, Formação Palermo.

\section{INTRODUCTION}

As recently shown by Holz et al. (2010), the Late Carboniferous/Permian succession of the eastern border of the Paraná Basin, encompasses seven Late Paleozoic thirdorder sequences (LPTS's), within a major second-order transgressive/regressive cycle [=Gondwana I Supersenquence of M illani et al. (2007)]. Invertebrate faunas of this succession are dominated by bivalves that flourished in a huge epeiric sea with a complex geological and ecological history. Paleoenvironmental history included depositional systems associated with glacial, fluvial deltaic-and marine to continental settings. Environmental changes al so included climatic warming towards the end of the Permian and fluctuations in 
salinity, oxygen content and sedimentation rate (Simões et al., 1998). Bivalves are especially common along the succession of LPTS-2 to 7, which have as stratigraphic equivalents the rocks of the Itararé, Guatá, and Passa Dois groups (see Figure 1). Bivalve faunas of the LPTS-2 to 4 (Itararé and Guatá groups) are more diverse, including subordinated brachiopods, gastropods, crustaceans, echinoderms and rare arenaceous foraminifers (Simões et al., 1998). A n opposed pattern is shown by the faunas of the LPTS-5 to 7, encompassing the entire Passa Dois Group. These are mainly dominated by infaunal shallow to intermediate and deep burrowing, filter-feeding bivalves, which are associated with rare epifaunal filter-feeding byssate species (Simões et al., 1998). As a whole, the Passa Dois bivalve faunas (except perhaps for the middle portion of the Rio do Rasto Formation) may have evolved in situ from stocks recorded in pre-Irati rocks, and also from other coeval $L$ ate Paleozoic marine successions of South A merica (Simões, 1992; Simões et al., 1998). Indeed, rocks of the main regressive phase (post-I rati times) harbor one of the most spectacular silicified Permian bivalve mollusk faunas of the world (M en-

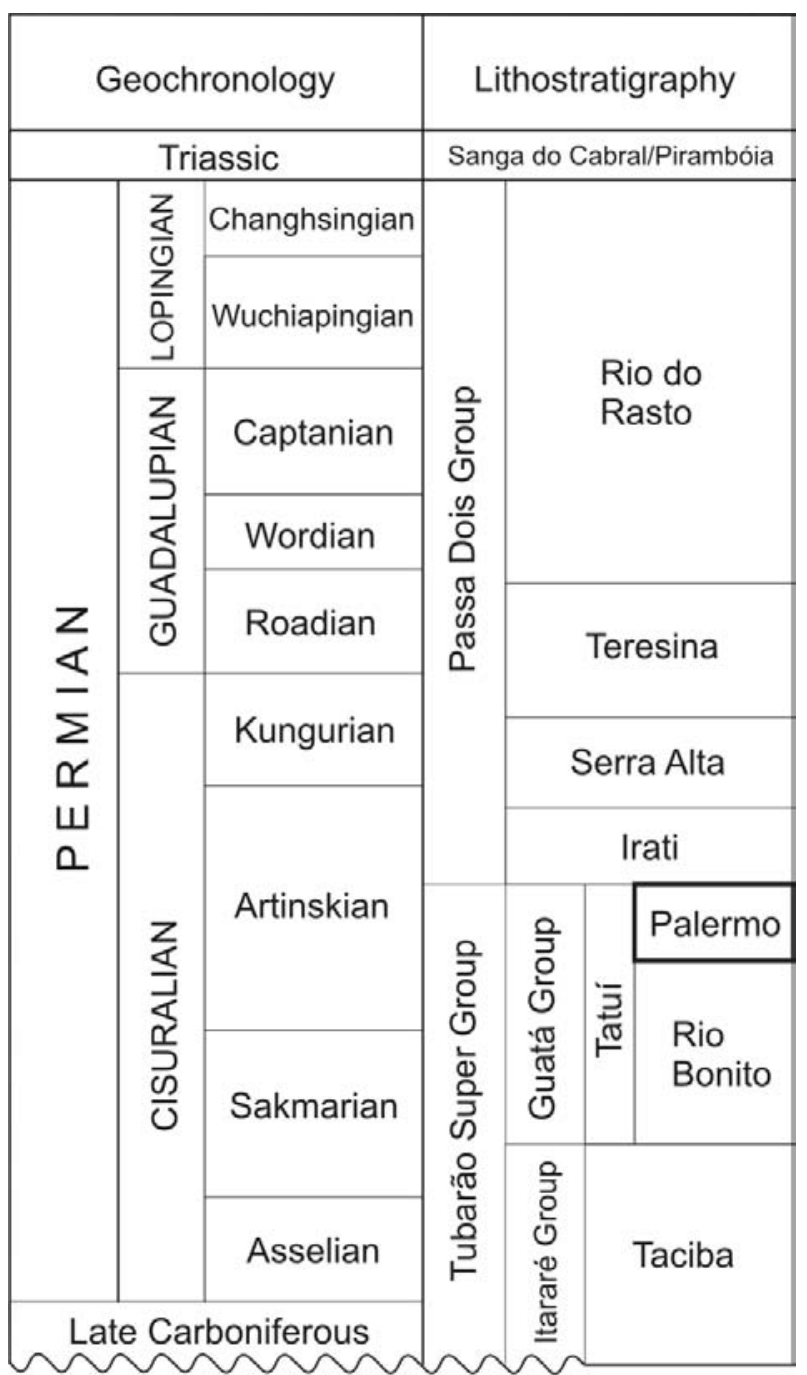

Figure 1. Geochronology and lithostratigraphy of the Permian Paraná Basin (based on Holz et al., 2010). des, 1952; Runnegar \& N ewell, 1971; Simões et al., 1997, 1998). During this phase, the Paraná (Passa Dois Group, Brazil), Karroo (Ecca Group, South A frica) and Huab (Gai-As Formation, Namibia) basins were a large aquatic (lake/sea) system of diversity and endemicity within the Gondwana supercontinent (R unnegar \& Newell, 1971; Simões et al., 1998; Wesselingh, 2007).

The post-Irati bivalve faunas of Paraná Basin are dominated by megadesmids (A nomalodesmata) (R unnegar \& Newell, 1971; Simões, 1992; Simões et al., 1997, 1998), a group that had attained high morphological disparity in some stratigraphic intervals (e.g. Corumbataí and Teresina formations, see Figure 1), and are highly endemic. However, the more realistic scenario of its in situ evolution is obscured by the poor knowledge of some bivalve species from preI rati rocks. For example, where and who are the early members of the lineages that gave rise to the endemic species that endured the strong intrabasinal radiation, after the anoxic events recorded by the black shales of the I rati succession? A ccording to our present knowledge, to solve this issue we may target the faunas of the Palermo/Tatuí interval (LPTS-3), below LPTS-4 (=I rati Formation), where rare occurrences of mollusk bival ve shells are known in the São Sepé region, Rio Grande do Sul State, and Guiratinga, M ato G rosso State (Petri \& Fúlfaro, 1966; 1983; Simões, 1992, 2000; Simões et al., 1998).

In the present contribution, we re-describe and interpret, for the first time, the affinities of a small unusual bivalve genus, named G uiratingia, first described by Petri \& Fúlfaro (1966), which occurs in sedimentary strata well below the Irati Formation or LPTS-4 succession (=Palermo Formation, see Figure 1). In other words, Guiratingia is found in sedimentary strata that are placed between the fully marine bivalve faunas of Rio Bonito Formation (LPTS-3) and the diverse endemic fauna of the Serra Alta, Teresina and Corumbataí formations (LPTS-6) (Simões, 1992; Simões et al., 1998). In this context, the new pal eontological data discussed herein add important information about the affinities and evolution of the bivalve fauna that thrived in the Permian Paraná B asin during its lake/sea phase.

\section{HISTORICAL BACKGROUND}

Shell-rich limestones of the Guiratinga region, cropping out in the northern margin of Paraná B asin (Figure 2), were originally found by Setembrino Petri during the geological campaign organized by the Division of Geology and $M$ ineralogy of the $N$ ational $D$ epartment of $M$ ineral Production to the states of Goiás and M ato Grosso in the year 1947. Although these occurrences were previously cited by Caster (1947) and subsequently by A Imeida $(1948,1954)$, the original description of the $G$ uiratingia mendesi only appeared in the paleontological literature nearly 20 years later (see Petri \& Fúlfaro, 1966).

Shells of G. mendesi arefound in partially silicified, pisolitic limestones intercalated in a thick succession of sandstones originally assigned to A quidauna rocks. In Guiratinga County, $M$ ato $G$ rosso, these pisolitic limestones are a few centimeters 


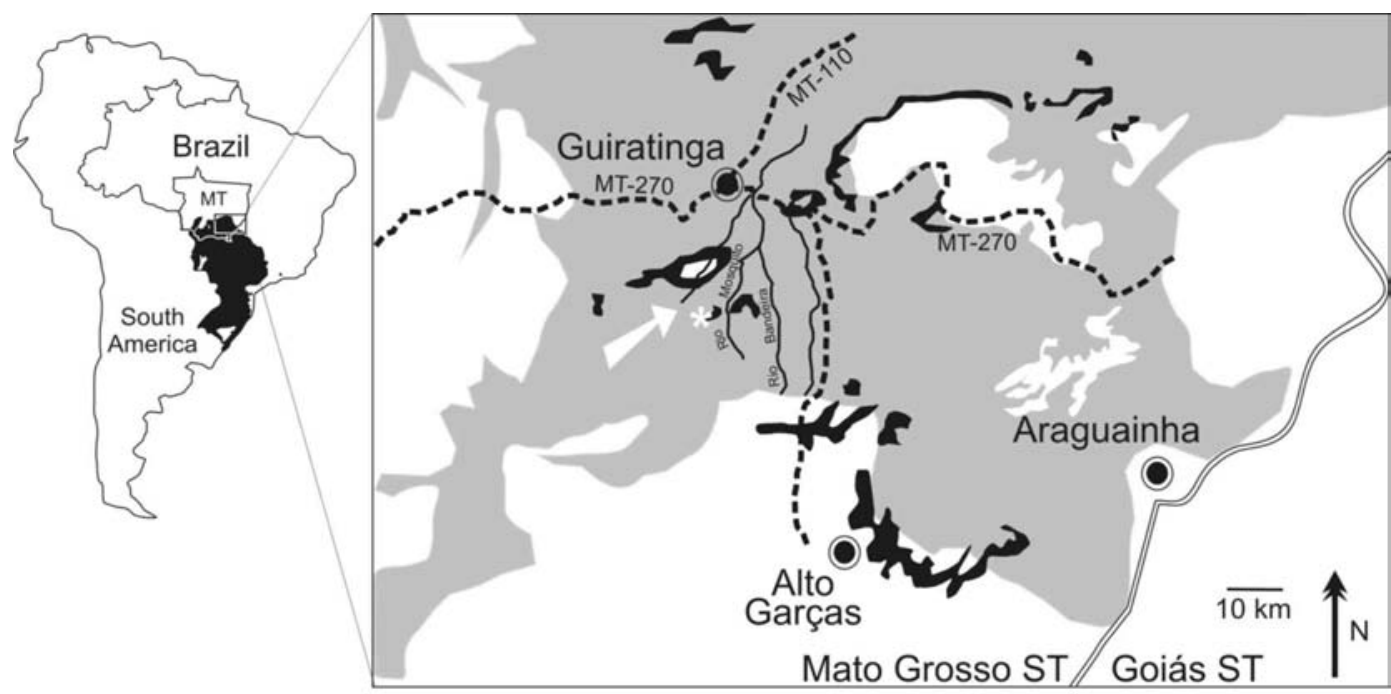

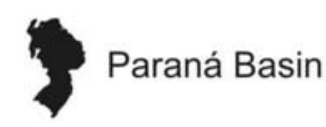

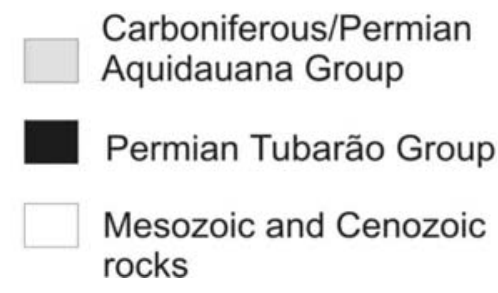

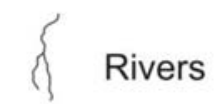

State Road

State Border

Guiratingia fossil site

Figure 2. Schematic map of the study area, Guiratinga County, State of Mato Grosso, Brazil, showing the location of the Guiratingia mendesi site.

thick and located nearly $100 \mathrm{~m}$ below the limestones of the Irati Formation (see Petri \& Fúlfaro, 1966, p. 70). Schneider et al. (1974) have correlated the Permian fossil-bearing beds of the $G$ ui ratinga region to the Pal ermo Formation. Bival ves are uncommon in this unit and coeval strata, and until now recorded only in scattered occurrences in Rio G rande do Sul State, such as the one in São Sepé region described by Simões (1992, 2000). In 1992, M.G. Simões called attention to the importance of $\mathrm{G}$. mendesi in the context of the evolution of Permian bivalves of the Paraná Basin. Since then, however, those shells were forgotten (except perhaps for brief reference in M ello, 1999), and only with renewed interest about the origin and evolution of bivalve faunas of the Permian Passa Dois Group (Wesselingh, 2007), were the specimens of $G$. mendesi brought to the scene again.

\section{MATERIAL AND METHODS}

In this study we re-analyzed the material of $\mathrm{G}$. mendesi originally described by Petri \& Fúlfaro (1966). O nly a few specimens are actually available for study, including rare silicified shells as well as more commonly internal and external molds. The specimens are housed in the scientific collection of the Institute of G eosciences, University of São Paulo, under the code DGP-7. The original material of Petri \& Fúlfaro (1966) was already prepared, and hence, in order to describe the anatomy of G. mendesi in as much detail as possible, we prepared plasticine casts of internal and external molds of isolated valves as well as internal molds of conjugated valves.

Suprageneric systematics was based on M orris et al. (1991), Runnegar \& Newell (1971), Runnegar (1974) and Simões et al. (1997). D escription of internal and external shell characters al so followed R unnegar \& N ewell (1971), R unnegar (1974), and Simões et al. (1997). Finally, interpretation of the mode of life of G. mendesi was based on Stanley (1970).

\section{SY STEMATIC PALEONTOLOGY}

Family M EGA DESM IDA E Vokes, 1967

Subfamily PLESIOCY PRINEL LIN A E Simões etal., 1997

Genus Guiratingia Petri \& Fúlfaro, 1966

Type species. Guiratingia mendesi Petri \& Fúlfaro, 1966 (by subsequent designation).

Diagnosis. Shell small, slightly expanded anteriorly; ventral surface of triangular blunt tooth in right valve weakly concave; a flexure of the shell delineates a flattened area alongside the commissure line, being more pronounced in the ventral margin; internal surface of the shell circumscribed by pallial line and adductor muscle scars, almost covered with mantle muscle striae. 
Type material. The lectotype (here designated) is DGP-7/ 1019 (Petri \& Fúlfaro, 1966, fig. 10; this paper, Figure 3A-P), Palermo Formation, Guatá Group, State of $M$ ato Grosso (Petri \& Fúlfaro, 1966, p. 76).

Paralectotypes. D GP-7/1018, 7/1019, 7/1020.

L ocality and horizon. Guiratinga County, M ato Grosso, B razil; Palermo Formation, near the Taboca River (see Petri \& Fúlfaro, 1966, for details).

Age. M iddleA rtinskian.

Remarks. The genus Guiratingia was erected by Petri \& Fúlfaro (1966), who based the diagnosis on a series of features representing nearly a complete description of a bivalve shell. G uiratingia shell is anteriorly expanded and has small digitate projections in the dorsal margin of pallial line, both characters considered within megadesmids as diagnostic features of Runnegariella (see Figure 3Q -R, and Simões \& A nelli, 1995). In some megadesmids, such as Runnegariella, Vacunella, $M$ yonia and others, striated scars possibly related to mantle muscles are aligned dorso-ventrally in the region enclosed by the pallial line and adductor muscle scars. These scars may appear in various shapes as pits, as in Vacunella, Pyramus, Myonia, or striae, as in Runnegariella and Guiratingia. The right valve of Guiratingia has a triangular blunt tooth with a slightly concave ventral face. This seems to be an intermediary condition between that observed in Pyramus and Cowperesia (triangular blunt tooth) and Plesiocyprinella (triangular blunt tooth with a concave ventral face).

\section{Guiratingia mendesi Figures $3 \mathrm{~A}-\mathrm{P}$}

Synonymy. Pyramus mendesi, Simões (1992), p. 234, pl. 2, figs. 2-3.

Other citations. Guiratingia mendesi, M ello (1999), p. 59, pl. 2, fig. 11.

Diagnosis. Same as generic diagnosis.

Description. Length of complete internal mold of $6.3 \mathrm{~mm}$, height of $4.6 \mathrm{~mm}$, and width of $2.6 \mathrm{~mm}$; oval in shape, equivalve, faintly inequilateral, with anterior portion of shell slightly expanded. M oderately elongated (elongation index varying from 1.28-1.36 for complete internal molds), compressed (obesity index of 1.80 for a complete internal mold). U mbones low with prosogyrous beaks; lunule and escutcheon absent. Ligament opisthodetic, parivincular, external, attached to short nymphs. Valve margins closed throughout commissure line. A flexure of the shell resulting from a conspicuous flattened area is visible ventral to the pallial line, alongside commissure, being more pronounced in the ventral margin. Right valve with a blunt tooth below beak; a corresponding socket is present in left valve. A nterior adductor muscle scar well impressed, with distinctly irregular posterior margin, slightly greater than posterior adductor muscle scar; anterior pedal retractor scar fused to the adductor muscle scar; pedal protractor muscle scar present. Posterior adductor more gently marked, with pedal retractor muscle scar fused to its dorsal extremity. U mbonal elevator muscle scar present at the beaks. Numerous wellmarked elongated mantle striae are present in the area circumscribed by pallial line and adductor muscle scars. Pallial line non-sinuate, very poorly striated, well marked, relatively thick, continuous. O rnamentation characterized by irregularly spaced, coarse comarginal growth lines.

Remarks. Guiratingia mendesi is the only species described for the genus. Its conspicuous combination of characters, however, gathers some rare morphological features present in younger endemic bivalves from the Permian Passa Dois Group. For example, shells of both $G$. mendesi and Runegariella fragilis found in limestones of the Teresina Formation are anteriorly expanded. A dditionally, these taxa share similar (i) mantle striae on the internal surface of shell, (ii) anterior adductor muscle scars with crenulated posterior margins, and (iii) striated pallial lines. However, a flexure is present only in the shell of $G$. mendesi. $Y$ et, its hinge is completely distinct from that of $R$. fragilis (Figures $3 Q-R$ ).

\section{DISCUSSION}

\section{Affinities and distribution of G uiratingia mendesi}

A ccording to Caster (1947), the bivalve specimens of the Guiratinga region of the State of $M$ ato Grosso were poorly preserved. However, Petri \& Fúlfaro (1966) were the first authors to note that the shells were in good preservation conditions, allowing the description of internal and external shell characters. A s we show ed here, the original specimens of Petri \& Fúlfaro (1966) are nicely preserved indeed, providing various key morphological features that are important in establishing its family affinities. Perhaps influenced by Mendes' studies of the Permian bivalves of the Paraná Basin (see M endes, 1944, 1952, 1954), Petri \& Fúlfaro (1966) left the question of family affinities of the genus Guiratingia open. It should be noted here that prior to the monographic study of R unnegar \& N ewell (1971), there was a generalized acceptance among $B$ razilian paleontologists that the bivalves of the middle and upper portions of the Permian succession of the Paraná B asin (LTPS- 6 and 7, = Serra A Ita, Teresina/Corumbataí and Rio do Rasto formations) were not similar to forms known outside the basin. Hence, many authors lost the chance to explain the family affinities of those bivalves.

A s observed by Petri \& Fúlfaro (1966) and more recently by M ello (1999), the small size of $G$. mendesi shells created difficulties in the interpretation of its original morphology. Because of that, these authors misinterpreted the general shell shape of $G$. mendesi, where the valves are anteriorly expanded, resembling Runnegariella from the faunas of the LPTS- 6 interval. Consequently, inaccurate interpretations of muscle scars of $G$. mendesi were also made with obvious implications for the interpretation of its general internal morphology and mode of life. A dditionally, some features related to the presence or absence of muscle scars were also misunderstood. As described above and shown in the Figures $3 A-P$, a number of characters related to hinge and muscle scars clearly indicates that $\mathrm{G}$. mendesi is related to megadesmid bivalves (see also Simões, 1992). A triangular 

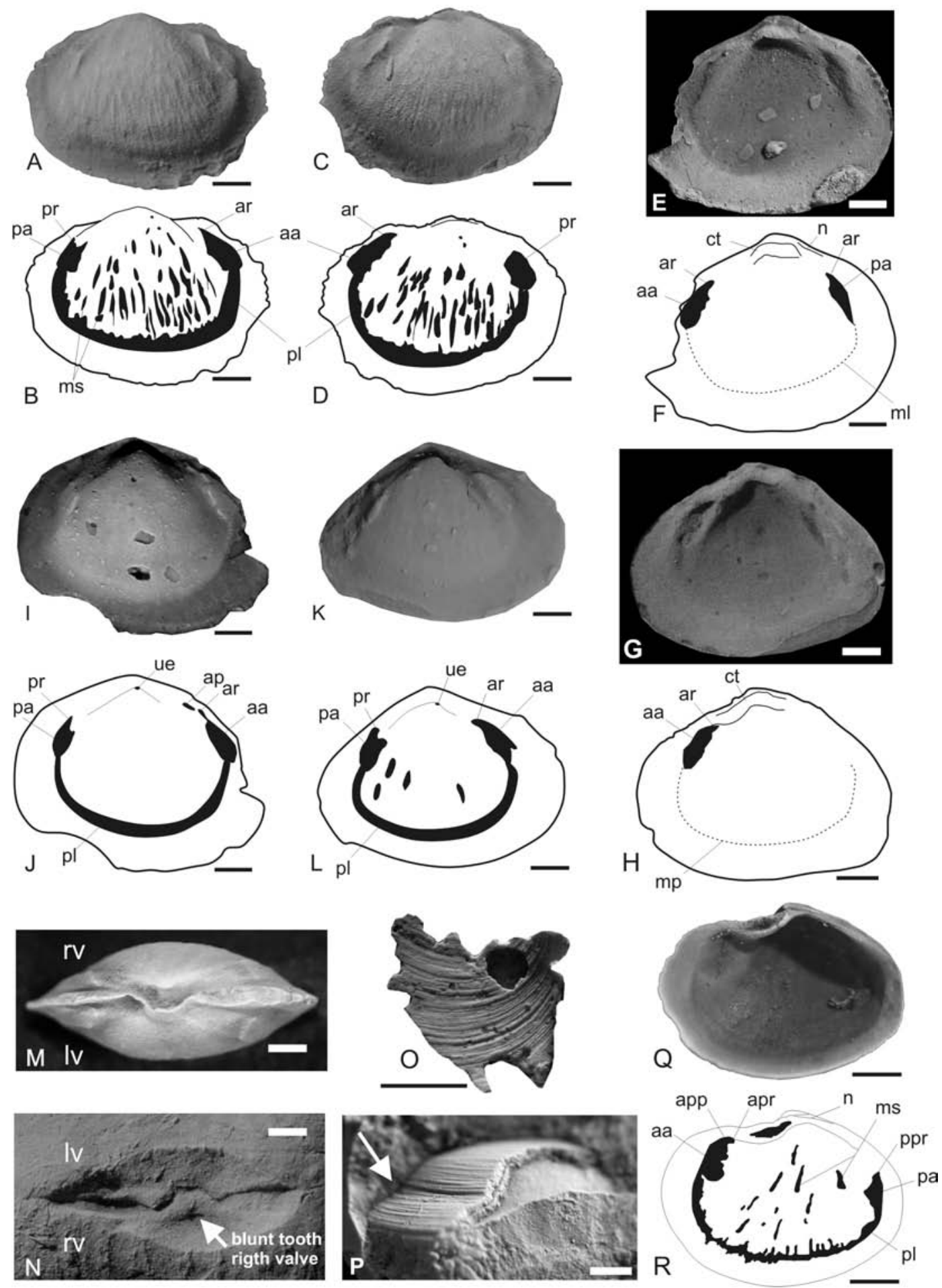

Figure 3. A-P, Guiratingia mendesi Petri \& Fúlfaro, 1966, Palermo Formation, Middle Permian. A, right valve view of an internal mold of conjugated valves, DGP 7/1019; B, muscle scars based on the same specimen, right valve view; C, left valve view of the same specimen; D, muscle scars based on the same specimen, left valve view; E, plasticine cast of an incomplete internal mold of right valve, DGP 7/1018; $\mathbf{F}$, muscle scars and hinge features based on the same specimen; G, plasticine cast of an incomplete internal mold of right valve, DGP 7/ 1020; H, muscle scars and hinge features based on the same specimen; I, incomplete internal mold of right valve, DGP 7/1018; J, muscle scars based on the same specimen; K, incomplete internal mold of right valve, DGP 7/1020; L, muscle scars based on the same specimen; $\mathbf{M}$, dorsal view of an internal mold of conjugated valves, DGP 7/1019; N, plasticine cast of hinge area of internal mold of conjugated valves, DGP 7/1019; $\mathbf{O}$, natural cast of external surface of shell showing pattern of growth lines; $\mathbf{P}$, fragmented silicified shell partially immersed in matrix, showing flexure of shell surface resulting in more flattened area below pallial line in internal mold, DGP 7/1019. Q-R, Runnegariella fragilis Simões \& Anelli, 1995. Q, silicified complete right valve, DZP 832; R, muscle scars based in the same specimen. Abbreviations. aa, anterior adductor; app, anterior pedal protractor; apr, anterior pedal retractor; bt, blunt tooth; dl, dorsal limit of flattened area; Iv, left valve; ms, muscle striae; n, nymph; pa, posterior adductor; pl, pallial line; pr, posterior retractor; rv, right valve; ue, umbonal elevator. Scale bars $=1 \mathrm{~mm}$ 
blunt tooth in the right valve is the only autapomorphy of the family M egadesmidae (Simões et al., 1997). Fortunately, the observation of this character was possible in plasticine casts made from a well-preserved internal mold (see Figures $3 \mathrm{E}-\mathrm{H}, \mathrm{N}$ ). A dditionally, in G. mendesi the pedal elevator muscle scars and the accessory muscle scars "a", " $b$ ", and "ava" of Runnegar $(1966,1974)$ are all absent(Figures 3B, D, F, J, L, H). The absence of these accessory muscle groups indicates that $\mathrm{G}$. mendesi belongs to the subfamily Plesiocyprinellinae (see Simões et al., 1997, p. 78).

All the observations above clearly show that: aM egadesmidae bivalves were al ready present in the Paraná B asin during the deposition of rocks of the Pal ermo Formation (LPTS-4), and b- Plesiocyprinellinae bivalves thrived in the Paraná $B$ asin, prior to I rati times. M embers of this subfamily were endemic to the Paraná B asin, and thus, its presence in pre-I rati rocks implies paleogeographic conditions favoring endemicity (e.g. restricted connections with open ocean waters). For example, bivalves of the LTPS-2 (Itararé G roup) and LPTS-3 (Rio Bonito Formation) successions are characteristically cosmopolitan and/or gondwanic in affinities. Although the Palermo succession records the second-order maximum flooding surface of the $L$ ate Paleozoic sequence of Paraná Basin (M ilani et al., 1994; Holz et al., 2010), during some intervals, restricted paleogeographic conditions prevailed, probably where coastal marine bayments had existed (see Holz et al., 2010). These marginal environments may have been the setting where $G$. mendesi flourished.

\section{Taphonomy and mode of life}

A s commented above, shells of $G$ uiratingia mendesi have been found in pisolitic limestones (Petri \& Fúlfaro, 1966). These shells are chaotically oriented and densely packed. Shells are usually nested and stacked, both closed articulated or disarticulated. Unfortunately, data about the lower and upper boundaries of those pisolitic limestone beds with the host sandstones are missing, but the chaotic orientation of shells and some taphonomic features such as nested and stacked shells are all signatures of storm shell beds ( $K$ idwell et al., 1986; K idwell \& Holland, 1991; Fürsich \& Oschmann, 1989, 1993; Simões et al., 1996). Hence, these were probably parautochthonous to allochthonous concentrations (sense Kidwell et al., 1986) of G. mendesi shells. A s indicated by Petri \& Fúlfaro (1966), other bivalves seem to be absent in those rocks. B ecause the shells of $G$. mendesi are extremely small, forming monospecific mass occurrences, it could be hypothesized that this species was a typical r-strategist, which lived in marginal habitats under high environmental stress. How ever, this notion should be viewed with caution because the taphonomic evidence above indicate transport or other taphonomic alteration (in the form of nested shells, for example). Hence, the monospecific mass occurrence of $G$. mendesi shells may result from size-sorting or winnowing during transport.
As described above, G. mendesi bears a thin, small, compressed, anteriorly expanded shell with a non-sinuate pallial line, and deeply impressed pedal scars (Figure 3). These features agree well with those summarized by Stanley (1970) for shallow, actively burrowing, suspension feeding bivalves. Thin, compressed shells are recorded in bivalves that are found in soft, soupy substrates. Guiratingia mendesi may have been a rapid burrower, as indicated by its anteriorly expanded shells. Indeed, according to Stanley (1970), shells with anterior length/total length ratio of 0.55 were rapid burrowers. This is a noticeable anatomical condition within Permian anomal odesmatans (Figure 4). Indeed, during their geological history of more than 400 million years, these bivalves showed various evolutionary trends (Runnegar, 1974; Harper et al., 2006), several of them related to adaptations for burrowing in different substrates under distinct sedimentary regimes. A s shown by R unnegar (1974), for example, there is convincing evidence of repeated adaptations for deep burrowing in various anomal odesmatan lineages. A nother possible trend is probably related to burrowing velocity and the emergence of the foot during burrowing in a direction nearly parallel to the long axis of the shell (R unnegar, 1974). A daptations related to this trend had led to the appearance of anteriorly expanded shells and also to the appearance of pedal gapes. Figure 4 illustrates this tendency, showing that the Permian genera Guiratingia and Runnegariella had anteriorly expanded shells, similar to those of the Cenozoic Verticordiidae genus E uciroa. This indicates that among anomalodesmatans, anteriorly expanded shells were al ready present in the Permian (Figure 4). As already suggested by Runnegar (1974), the presence of this condition among other M esozoic and Cenozoic anomalodesmatans is compelling evidence of recurring adaptations to burrowing by means of an anteriorly emergent foot, along the evolutionary history of this fascinating group of bivalves.

\section{FINAL COMMENTS}

The mollusk radiation recorded in the Permian succession of Paraná Basin (Runnegar \& Newell, 1971; Simões et al., 1998; Wesselingh, 2007) was one of the most significant events in the history of A nomalodesmatan bivalves. This evolutionary event provides a unique opportunity to examine paleoecological changes through the course of a radiation within a clade (Simões et al., 1997), since there is a reasonable record of megadesmids before and after the I rati anoxic crises. However, the study of this radiation is hindered by the fact that the sedimentary succession studied is not a continuous record of successive faunas, but rather it is punctuated by several unconformities showing a hiatus of variable temporal magnitudes (see Holz et al., 2010). A dditional ly, on the eastern border of the Paraná B asin, rocks of the marginal environments of the Irati succession were partially eroded, and minor sequence boundaries are also recorded within the Teresina succession (see H olz et al., 2010). In particular, there is a significant hiatus between the top of 


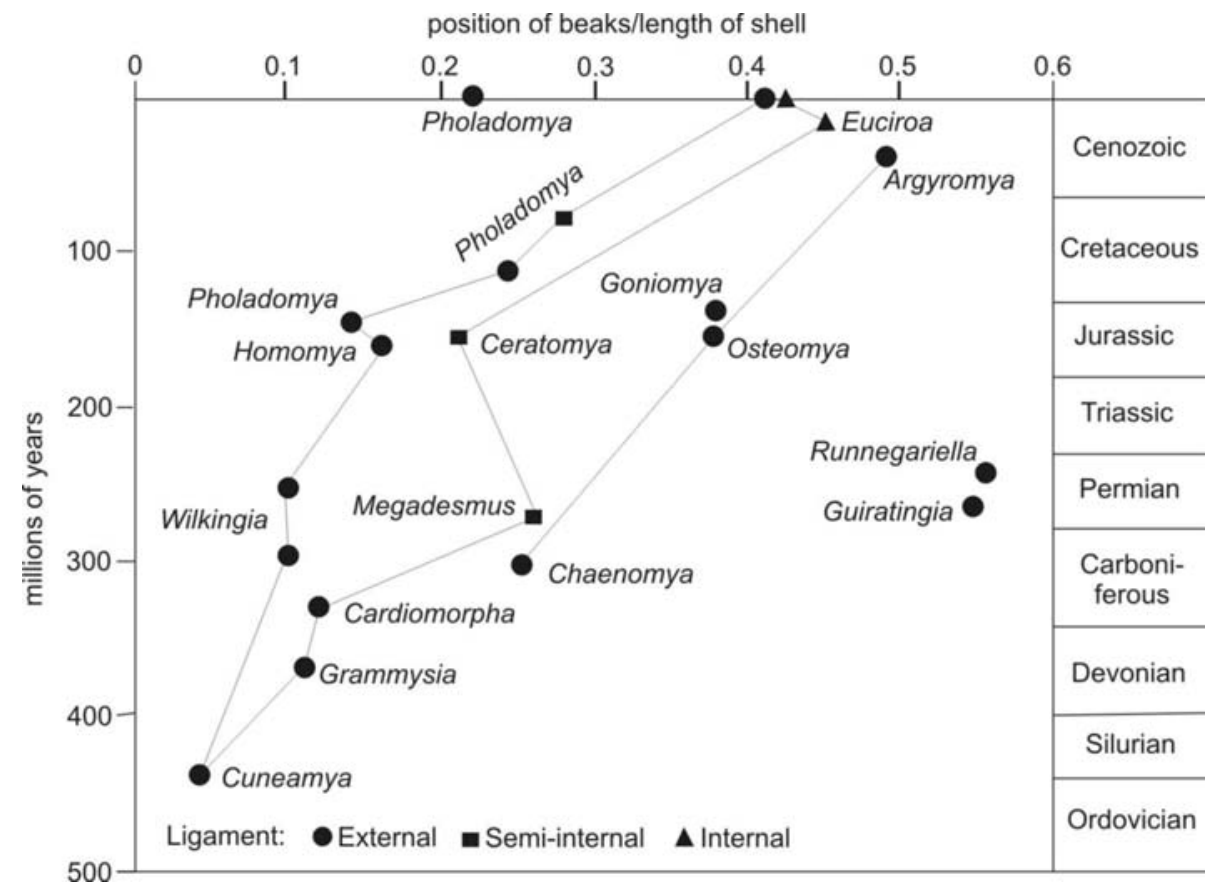

Figure 4. Parallel trends of posterior migration of the umbones in both shallow and deep burrowing anomalodesmatan bivalves (modified from Runnegar, 1974 and Anelli \& Simões, 1995).

Table 1. Measurements (mm) of Guiratingia mendesi. Elongation index (length/height) and obesity (height/width) according to Stanley (1970).

\begin{tabular}{|c|c|c|c|c|c|c|}
\hline Specimen Code & Material & Length & Height & Width & Elongation & Obesity \\
\hline GPE 7/1018 & $\begin{array}{l}\text { incomplete, } \\
\text { internal mold, } \\
\text { right valve }\end{array}$ & 5 & 4.7 & -- & 1.06 & -- \\
\hline GPE 7/1019 & $\begin{array}{l}\text { intemal mold, } \\
\text { right valve of } \\
\text { conjugated } \\
\text { valves }\end{array}$ & 6.35 & 4.64 & 2.57 & 1.36 & 1.80 \\
\hline GPE 7/1020 & $\begin{array}{l}\text { intemal mold, } \\
\text { right valve }\end{array}$ & 6.8 & 5.3 & -- & 1.28 & -- \\
\hline
\end{tabular}

the Palermo/Tatui (LPTS-4) unitand the base of the I rati (LPTS5) succession, which gives rise to the sequence boundary SB -5 of the stratigraphic chart of Holz et al. (2010). In the same way, the top of the I rati (LPTS-5) and SerraA Ita (LPTS6) units are marked by the sequence boundary SB - 6 ( $\mathrm{Holz}$ et al., 2010). These indicate that the rock record of the preradiation phase (below SB -5) and main radiation event (above SB -6) of the evolutionary history of megadesmids within the Paraná B asin is incomplete (biased).

Despite the issues described above, the rock succession recording G. mendesi and the so-called São Sepébivalve fauna (Simões, 1992, 2000; Simões et al., 1998) can offer us a little glimpse of the taxonomic composition, affinities and mode of the life of the bivalve faunas prior to the megadesmid radiation within Paranálake/sea, and the euxinic event recorded by the black shales of the I rati succession (LPTS-5). Finally, of particular importance is the mode of life of $G$. mendesi, and its anteriorly expanded valves, a shell condition rarely seen in megadesmids and also present in Mesozoic and Cenozoic anomal odesmatans.

\section{ACKNOWLEDGMENTS}

This study is a contribution to the following projects: FAPESP (96/9708-9), and CN Pq (500694/92-3, 151853/20088). We thank C. B. Kotzian and M. Clapham for their constructive remarks.

\section{REFERENCES}

A Imeida, F.F.M . 1948. Contribuição à geologia do estado de G oiás e Mato Grosso. Rio de Janeiro, Departamento Nacional de Produção M ineral, Divisão de Geologia e M ineralogia, 18 p. (Notas Preliminares e Estudos 46).

A Imeida, F.F.M., 1954. G eologia do centro-leste mato-grossense. Rio de J aneiro, Departamento Nacional de Produção M ineral, Divisão de G eologia e M ineralogia, 97 p. (B oletim 150).

Caster, K.E. 1947. Expedição geológica em Goiás e M ato Grosso. M ineralogia e M etalogenia, 12:126-127.

Fürsich, F.T. \& Oschmann, W. 1986. Storm shell beds of Nanogyra virgula in the U pper J urassic of France. Neues J ahrbuch für $G$ eologie und Paläontologie, 172:141-161. 
Fürsich, F.T. \& Oschmann, W. 1993. Shell beds as tools in basin analysis: the Jurassic Kachchh, western India. J ournal of Geological Society of London, 150:169-185.

Harper, E.M.; Dreyer, H. \& Steiner, G. 2006. Reconstructing the A nomalodesmata (M ollusca: Bivalvia): morphology and molecules. Zoological J ournal of the Linnean Society, 148:395420.

Holz, M.; França, A.B.; Souza, P.A.; Iannuzzi, R. \& Rohn, R. 2010. A stratigraphic chart of the $L$ ate $C$ arboniferous/Permian succession of the eastern border of the Paraná Basin, Brazil, South A merica. J ournal of South American Earth Sciences, 29:381-399.

Kidwell, S.M .; Fürsich, F.T. \& Aigner, T. 1986. Conceptual framework for the analysis of fossil concentrations. Palaios, 1:228-238.

Kidwell, S.M . \& Holland, S.M. 1991. Field description of coarse bioclastic fabrics. Palaios, 6:426-434.

M ello, L.H.C. 1999. A nálise cladística dos bivalves do G rupo Passa Dois (Neopermiano), Bacia do Paraná, Brasil: implicações taxonômicas, evolutivas e paleobiogeográficas. Programa de Pós-graduação em G eologia Sedimentar, U niversidade de São Paulo, M.Sc. thesis, 160 p.

M endes, J.C. 1944. Lamelibrânquios triássicos de Rio Claro. Boletim da Faculdade de Filosofia Ciências e Letras, Série G eologia, 45:41-75.

M endes, J.C. 1952. A Formação Corumbataí na região do Rio Corumbataí (estratigrafia e descrição dos lamelibrânquios). Boletim da Faculdade de Filosofia Ciências e Letras, Série Geologia, 145(8):1-119.

M endes, J.C. 1954. Contribui ção à estratigrafia da Série Passa D ois no Estado do Paraná. B ol etim da F aculdade de Filosofia Ciências e Letras, Série G eologia, 175(10):1-119.

M ilani, E.J .; França, A.B . \& Schneider, R.L. 1994. B acia do Paraná. Boletim Geociências da P etrobrás, 8:69-82.

M ilani, E.J .; M elo, J.H.G.; Souza, P.A .; Fernandes, L.A.\& França, A.B. 2007. Bacia do Paraná. Boletim de Geociências da Petrobrás, 15:265-287.

M orris N.J .; Dickins, J.M . \& A stafieva-Urbaitis, K. 1991. Upper Paleozoic A nomalodesmatan Bivalvia. Bulletin of the British M useum of Natural History, Geology, 47:51-100.

Petri, S. \& Fúlfaro, V.J . 1966. Sobre a geologia das cidades balizadas pelas cidades de Barra do Garça e Guiratinga, M ato Grosso e Jataí A morinópolis, Goiás. Boletim da Sociedade Brasileira de Geologia, 15:59-80.

Petri, S. \& Fúlfaro, V.J . 1983. Geologia do Brasil (Fanerozóico). São Paulo, EDUSP, 631 p.

Runnegar, B. 1974. Evolutionary history of the bivalve Subclass A nomal odesmata. J ournal of Paleontology, 48:904-939.

Runnegar, B. 1966. Systematic and biology of some desmodont bivalves from the A ustralian Permian. J ournal of G eological Society of Australia, 13(2):373-386.

Runnegar, B.\& Newell, N.D. 1971. Caspian-like relict molluscan fauna in South A merican Permian. Bulletin of the American M useum of Natural History, 146:1-66.

Schneider, R.L.; M ühlmann, H.; Tommasi, E.; M edeiros, R.A.; Daemon, R.F.\& N ogueira, A.A . 1974. R evisão estratigráfica da bacia do Paraná. In: CONGRESSO BRASILEIRO DE GEOLOGIA, 28, 1974. Anais, Porto A legre, SBG, p. 41-65.

Simões, M .G. 1992. Pelecípodes da F ormação Palermo (Permiano) de São Sepé, RS e Guiratinga, MT: implicações na evolução dos invertebrados da Bacia do Paraná, Brasil. Programa de Pós-graduação em Geologia Sedimentar, U niversidade de São Paulo, Ph.D. thesis, $286 \mathrm{p}$.

Simões, M.G. 2000. A ssembléias de invertebrados marinhos do Neopaleozóico da bacia do Paraná, no Estado do Rio Grande do Sul, Brasil. In: M. Holz \& . L.F. de Ros (orgs.) Paleontologia do Rio Grande do Sul, Editora da UFRGS, p. 107-125.

Simões, M .G. \& A nelli, L.E. 1995. Runnegariella, um novo gênero de M egadesmidae (Pelecypoda) da Formação Corumbataí (Neopermiano), bacia do Paraná, B rasil. R evista Geociências, 14:161-173.

Simões, M.G.; M arques, A.C.; M ello, L.H.C.\& A nelli, L.E. 1997. Phylogenetic analysis of the genera of the extinct family M egadesmidae (Pelecypoda, A nomalodesmata), with remarks on its paleoecology and taxonomy. Journal of Comparative Biology, 2:75-90.

Simões, M.G.; Rocha-Campos, A.C.\& A nelli, L.E. 1998. Paleoecology and evolution of Permian pelecypod assemblages (Paraná B asin) from B razil. In: P.A. Johnston \& J.W. Haggart (eds.) Bivalves - an eon of evolution: paleobiological studies honoring Norman D. Newell, U niversity of Calgary Press, $p$. 443-452.

Simões, M .G.; Torello, F.F. \& Rocha-Campos, A.C. 1996. Gênese e classificação da coquina de Camaquã (A ssembléia de Pinzonella neotropica), Formação Corumbataí (Permiano superior), Rio Claro, SP. A nais da Academia Brasileira de Ciências, 68:545-557.

Stanley, S.M. 1970. Relation of shell form to life habits of the Bivalvia (Mollusca). Geological Society of America Memoir, 125:1-296.

Vokes, H.E. 1967. Genera of the Bivalvia: a systematic and bibliographic catalogue. Bulletin of the American Pal eontologist, 51:111-393.

Wesselingh, F.P. 2007. L ong-lived lake molluscs as island faunas: a bivalve perspective. In: W. Renema (ed.) Biogeography, time and place: distributions, barriers and islands, Springer, p. 275314.

Received in December, 2009; accepted in May, 2010. 